\title{
Virus-driven nitrogen cycling enhances phytoplankton growth
}

\author{
Emma J. Shelford ${ }^{1}$, Mathias Middelboe ${ }^{4}$, Eva F. Møller ${ }^{5}$, Curtis A. Suttle ${ }^{1,2,3, *}$ \\ ${ }^{1}$ Department of Earth and Ocean Sciences, ${ }^{2}$ Department of Botany, and ${ }^{3}$ Department of Immunology and Microbiology, \\ University of British Columbia, Vancouver, British Columbia, V6T 1Z4, Canada \\ ${ }^{4}$ Marine Biological Section, University of Copenhagen, 3000, Helsingør, Denmark \\ ${ }^{5}$ National Environmental Research Institute, Aarhus University, 4000, Roskilde, Denmark
}

\begin{abstract}
Viruses have been implicated as major players in aquatic nutrient cycling, yet few data exist to quantify their significance. To determine the effect of viruses on ammonium regeneration by bacteria, experiments were carried out in the oligotrophic Indian Ocean and productive False Creek, Vancouver, Canada. Bacteria were concentrated and then diluted with virus-free water to reduce virus abundance, or with virus-replete water to restore natural virus abundances. Virus-replete treatments showed increased ammonium concentrations compared to treatments with viruses removed (differences of $0.287 \pm 0.14$ and $1.44 \pm 0.73 \mu \mathrm{mol} \mathrm{l}^{-1}$, mean $\pm \mathrm{SD}$, in the Indian Ocean and False Creek, respectively). Bacterial abundances were lower, while phytoplankton abundances and chlorophyll $a(\mathrm{chl} a)$ concentrations were greater in the virus-replete treatments, consistent with the increased availability of ammonium in the presence of viruses. These data demonstrate that viral lysis leads to ammonium production, likely through the liberation of dissolved organic $\mathrm{N}$ that is remineralised by uninfected bacteria. In turn, the released ammonium fuels primary production. These results show that viruses play a critical role in the marine $\mathrm{N}$ cycle, and suggest that viral lysis likely supplies a significant portion of the global $\mathrm{N}$ requirements of phytoplankton.
\end{abstract}

KEY WORDS: Ammonium $\cdot$ Virus $\cdot$ Bacteria $\cdot$ Remineralisation $\cdot$ Nitrogen

\section{INTRODUCTION}

Viruses are the most abundant biological entities in the ocean, of which the majority are thought to infect bacteria (Suttle 2007). Every day, viruses lyse an estimated 20 to $40 \%$ of the bacterial production in the ocean (Suttle 1994), releasing bacterial cell contents to the surrounding environment. This process has been termed the 'viral shunt', to describe the viralmediated transfer of nutrients from particulate to dissolved material (Wilhelm \& Suttle 1999, Suttle 2005). The lysis products are used by uninfected bacteria (Middelboe et al. 1996, 2003); therefore, viruses play an important role in recycling carbon and nutrients within the bacterial community. Viral loop models (e.g. Fuhrman 1992, Bratbak et al. 1994) incorporate virus-induced cycling of carbon within the bacterial size fraction into the pelagic food web model, and suggest that viral activity primarily acts as a sink of organic carbon by removing whole cells from grazing and increasing bacterial respiration. This was verified experimentally by Middelboe \& Lyck (2002), in a study in which viral activity stimulated carbon recycling and respiration by uninfected bacteria, and reduced the accumulation of microbial biomass. Further studies have confirmed efficient bacterial recycling of carbon from bacterial (Middelboe et al. 2003) or algal lysates (Haaber \& Middelboe 2009). 
There is also persuasive evidence that viruses are important agents of $\mathrm{N}$ cycling in aquatic environments. Viral lysates are rich in free and combined amino acids (Middelboe \& Jørgensen 2006), and are therefore a potentially important source of labile organic N. Moreover, bacteria assimilate dissolved organic nitrogen (DON) resulting from the lysis of infected microorganisms, especially when nutrientlimited (Gobler et al. 1997). During carbon-limited conditions, bacteria hydrolyse amino acids and other nitrogenous products to access the carbon, producing ammonium as a by-product (Goldman et al. 1987). Assuming that the $\mathrm{C}: \mathrm{N}$ ratio of viral lysates is similar to that of bacteria (i.e. between 4:1 and 5:1; Goldman et al. 1987) and that carbon growth efficiencies of uninfected bacteria are in the range of 0.2 to 0.3 (Middelboe et al. 1996), viral lysates contain $\mathrm{N}$ in excess of bacterial requirements. Consequently, bacterial metabolism of viral lysates should produce inorganic $\mathrm{N}$ that is available to phytoplankton (Haaber \& Middelboe 2009). In addition to fuelling bacterial metabolism, viral lysis therefore may represent a significant pathway for the regeneration of ammonium, a major $\mathrm{N}$ source that fuels primary production in the ocean.

We hypothesise that viral lysis of bacteria releases cellular debris to the dissolved organic matter (DOM) pool, accessible to uninfected bacteria. The subsequent turnover is potentially an important source of $\mathrm{N}$ for phytoplankton growth (e.g. Haaber \& Middelboe 2009). Therefore, viral activity would not only be a carbon sink, but would also indirectly stimulate primary productivity, and thus carbon production. The strongest evidence that viral lysis supports the growth of phytoplankton was seen in several experiments conducted in the Gulf of Mexico and Mediterranean in which the growth rates and the proportion of dividing Synechococcus cells were higher in treatments with viruses than in treatments in which viral concentration was either reduced by dilution with ultra-filtered seawater or was heat-inactivated (Weinbauer et al. 2011).

To determine whether ammonium regeneration associated with viral lysis influences phytoplankton growth, an initial experiment was conducted in the oligotrophic Indian Ocean and followed up with an experiment in False Creek, a small productive inlet by Vancouver, Canada. The experiments showed a decrease of ammonium regeneration with removal of viruses, and a subsequent decrease in phytoplankton growth. These data are significant because they not only quantify and verify the significance of viruses in regenerating $N$, but also support the view that viruses are not simply parasites that disrupt food web flow (Azam \& Worden 2004), but play a significant role in nutrient recycling (Fuhrman 1999, Wilhelm \& Suttle 1999) and ultimately provide $\mathrm{N}$ that supports primary production.

\section{MATERIALS AND METHODS}

\section{Description of sampling sites}

Samples were collected from the surface waters of False Creek (FC), Vancouver, Canada (49 $16^{\prime} \mathrm{N}$, $123^{\circ} 7^{\prime} \mathrm{W}$ ) on 3 November 2008, and from $10 \mathrm{~m}$ depth in the Indian Ocean (IO) $\left(19^{\circ} 46^{\prime} \mathrm{S}, 114^{\circ} 52^{\prime} \mathrm{E}\right)$ on 12 November 2006. The 2 study sites represented very different environments. The IO station is oceanic and oligotrophic with a high degree of DOM recycling (A. W. Visser et al. unpubl. data), and was characterized by very low concentrations of chlorophyll a (chl $a_{i} \quad 0.2 \mu g \mathrm{l}^{-1}$ ), inorganic nutrients (nitrate, $0.12 \mu \mathrm{mol} \mathrm{l}^{-1}$; phosphate, $0.08 \mathrm{\mu mol} \mathrm{l}^{-1}$; ammonium, $0.16 \mu \mathrm{mol} \mathrm{l} \mathrm{l}^{-1}$ ), a sea surface temperature of $28^{\circ} \mathrm{C}$, and a salinity of 35.0. In contrast, FC is a small productive inlet which is heavily influenced by neighbouring English Bay, the Fraser River, and freshwater runoff from the City of Vancouver. Tidal mixing results in a vigorous exchange of water between the sampling site at the mouth of FC and English Bay. Surface salinities in English Bay typically remain at 25 to 26 during November and December (Short \& Suttle 2003), and temperatures range from $\sim 7$ to $10^{\circ} \mathrm{C}$. These data are consistent with sea-surface temperatures for November 2008 of $10^{\circ} \mathrm{C}$ estimated from satellite data (http://las.pfeg.noaa.gov/oceanWatch/ oceanwatch.php). In November, chl a was low $\left(0.47 \mu \mathrm{g} \mathrm{l}^{-1}\right)$, and nutrient concentrations high (nitrate, $14.8 \mathrm{mmol} \mathrm{l}^{-1}$; phosphate, $1.43 \mathrm{mmol} \mathrm{l}^{-1}$; ammonium, $3.50 \mu_{\mathrm{mol} \mathrm{l}}^{-1}$ ).

\section{Experimental design}

The IO and FC experiments were designed to examine the impact of viruses on ammonium production and subsequent effects on phytoplankton growth. In both experiments, triplicate $+\mathrm{V}$ and $-\mathrm{V}$ treatments were set up with the objectives of keeping bacterial abundances at near in situ levels in both treatments, while reducing $(-\mathrm{V})$ or maintaining $(+\mathrm{V})$ near in situ viral abundances.

In the FC experiment, water was filtered in series through 2.0 and $0.2 \mu \mathrm{m}$ pore-size, $47 \mathrm{~mm}$ diameter 
polycarbonate filters (AMD Manufacturing), with the first filter removing larger phytoplankton and zooplankton, and the second concentrating bacteria (Wilhelm et al. 2002). A transfer pipette was used to keep the bacteria in suspension above the $0.2 \mu \mathrm{m}$ filter. Viruses were removed using a Prep Scale-TFF Cartridge (Millipore) with a $30 \mathrm{kDa}$ molecular weight cut-off. The $-\mathrm{V}$ treatment was prepared by adding $50 \mathrm{ml}$ of bacterial concentrate to $450 \mathrm{ml}$ of virus-free water, and the $+\mathrm{V}$ treatment was prepared by adding $50 \mathrm{ml}$ of bacterial concentrate to $450 \mathrm{ml}$ of $0.2 \mu \mathrm{m}$ filtered water. Incubations ran on a light:dark cycle of $14: 10 \mathrm{~h}$ at in situ temperature, and subsamples were collected at time $0,5.5,10.25,19$, and $24.5 \mathrm{~h}$.

The IO experiment was performed similarly; however, water was filtered through a $20 \mu \mathrm{m}$ pore-size filter before bacteria were concentrated above a $0.2 \mu \mathrm{m}$ pore-size Pellicon filter (Millipore), and viruses were removed using a $47 \mathrm{~mm}$ diameter $0.02 \mu \mathrm{m}$ pore-size Anodisc filter (Whatman). Incubations were run at in situ light and temperature conditions in flow-through, on-deck incubators, and subsamples were collected at $0,6,10.5,17.5$, and $23.5 \mathrm{~h}$. The effect of the concentration step on bacterial production in the IO experiment was measured using tritiated thymidine (TdR) incorporation (Fuhrman \& Azam 1980). TdR incorporation rate, normalised per cell, was $12 \pm 5 \%$ higher in untreated water than after the concentration step, indicating a minor effect of the procedure.

\section{Cell and virus counts}

Volumes of $1 \mathrm{ml}$ (viruses and bacteria) and $5 \mathrm{ml}$ (phytoplankton) were fixed with gluteraldehyde at a final concentration of $0.5 \%$, frozen in liquid $\mathrm{N}$, and stored at $-80^{\circ} \mathrm{C}$. Samples were counted using a Becton Dickinson FACSCalibur flow cytometer, using SYBR Green I (Sigma-Aldrich) to stain the viruses and bacteria (Brussaard 2004). Phytoplankton were enumerated unstained (Olsen et al. 1993).

\section{Chlorophyll and nutrient determinations}

Samples were filtered through acid-washed syringes fitted with Milli-Q-soaked $0.45 \mu \mathrm{m}$ pore-size cellulose-nitrate membrane filters (Whatman Schleicher \& Schnell). The first $5 \mathrm{ml}$ were discarded, and the rest was collected into acid-washed $15 \mathrm{ml}$ polypropylene screw cap tubes and frozen at $-20^{\circ} \mathrm{C}$. The filters were folded and placed in similar screw cap tubes, kept in the dark, and frozen at $-20^{\circ} \mathrm{C}$. $\mathrm{Chl} \mathrm{a}$ and ammonium were determined fluorometrically following the respective protocols of Parsons et al. (1984) and Holmes et al. (1999).

\section{Statistical methods}

Differences of means were tested using 2-tailed Student's $t$-tests. Equality of variance was tested using an $F$-test.

\section{RESULTS}

\section{Bacterial and viral abundances}

Bacterial and viral abundances (mean $\pm \mathrm{SD}$ ) in the initial water samples at IO and FC were $8.61 \pm 0.45 \times$ $10^{5}$ and $19.1 \pm 1.58 \times 10^{5}$ cells ml $^{-1}$ and $15.3 \pm 5.4 \times$ $10^{6}$ and $17.3 \pm 1.72 \times 10^{6}$ viruses $\mathrm{ml}^{-1}$, respectively. As expected, viral abundances at the start of the IO and FC experiments were significantly less in the $-\mathrm{V}$ than in the $+\mathrm{V}$ treatments (IO: decrease of $70 \%, t=$ 36.7, $\mathrm{df}=2, \mathrm{p}<0.001$; FC: decrease of $39 \%, t=3.88$, $\mathrm{df}=4, \mathrm{p}<0.05 ; 2$-tailed Student's $t$-test). Increase in viral abundance over the FC experiment was significantly greater in $+\mathrm{V}$ than in $-\mathrm{V}$ (Fig. $1 \mathrm{~B} ; t=4.30, \mathrm{df}=$ $2, \mathrm{p}<0.001 ; 2$-tailed Student's $t$-test). Time-course data for the IO experiment indicates that viral production occurred in the $+\mathrm{V}$ treatment (Fig. 1A), although there was a net decrease of viral abundance from the initial to final time point.

\section{Phytoplankton growth}

In the FC samples, small cyanobacteria that were not removed by $2 \mu \mathrm{m}$ filtration increased significantly in $+\mathrm{V}$ compared to $-\mathrm{V}$ treatments $(t=3.88, \mathrm{df}=4$, $\mathrm{p}<0.05$; 2-tailed Student's $t$-test), consistent with the increase in chl $a$ in $+\mathrm{V}$ (Fig. 2). In the IO samples, $\mathrm{chl} a$ increased in the $+\mathrm{V}$ treatment and decreased in the $-\mathrm{V}$ treatment, with significant differences between treatments at the final time point $(t=2.78, \mathrm{df}$ $=4, \mathrm{p}<0.05 ; 2$-tailed Student's $t$-test).

\section{Ammonium concentrations}

Ammonium concentrations were initially indistinguishable in $+\mathrm{V}$ and $-\mathrm{V}$ for both experiments (IO: $+\mathrm{V}$ $=0.25 \pm 0.02 \mathrm{~mol} \mathrm{l}^{-1},-\mathrm{V}=0.22 \pm 0.02 \mu \mathrm{mol} \mathrm{l}^{-1}$; FC: 


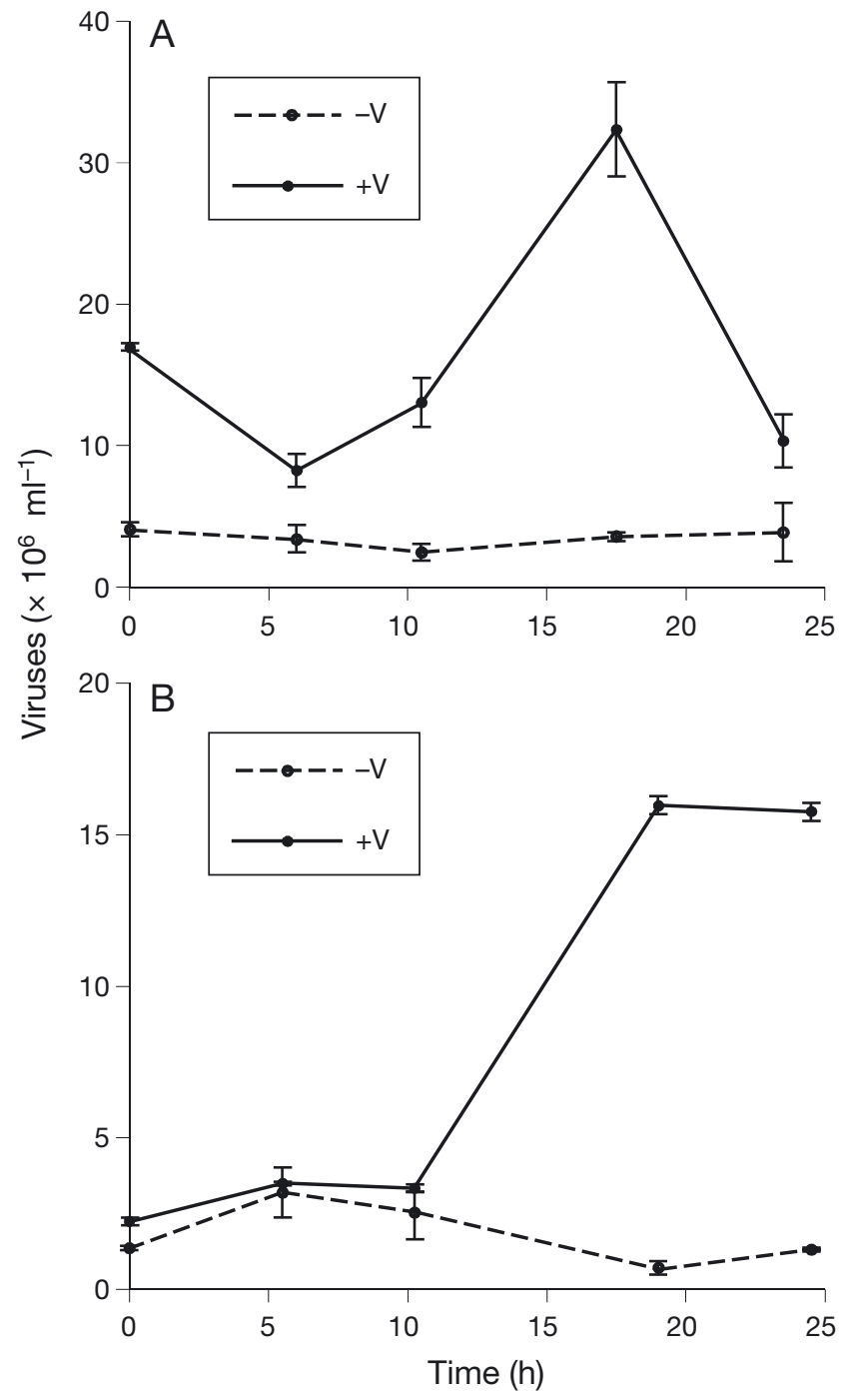

Fig. 1. Time series of viral abundance in seawater samples from (A) the Indian Ocean (IO) and (B) False Creek (FC) experiments in which viruses had been reduced $(-\mathrm{V})$ or maintained at near in situ abundance $(+\mathrm{V})$. Error bars represent the SD of abundance estimates from triplicate incubations

$+\mathrm{V}=3.38 \pm 0.12 \mu \mathrm{mol} \mathrm{l}^{-1},-\mathrm{V}=3.13 \pm 0.18 \mu \mathrm{mol} \mathrm{l}^{-1}$ ), but at the end of both experiments were significantly higher in $+\mathrm{V}$ than in $-\mathrm{V}$ (Fig. 3 ; IO: $t=7.00, \mathrm{df}=4$, $\mathrm{p}<0.005$; FC: $t=4.55, \mathrm{df}=4, \mathrm{p}<0.05 ;$ 2-tailed Student's $t$-test).

\section{DISCUSSION}

The most important findings of the present study were that ammonium and chlorophyll production decreased in temperate and tropical seawater samples in which viral abundances were reduced.

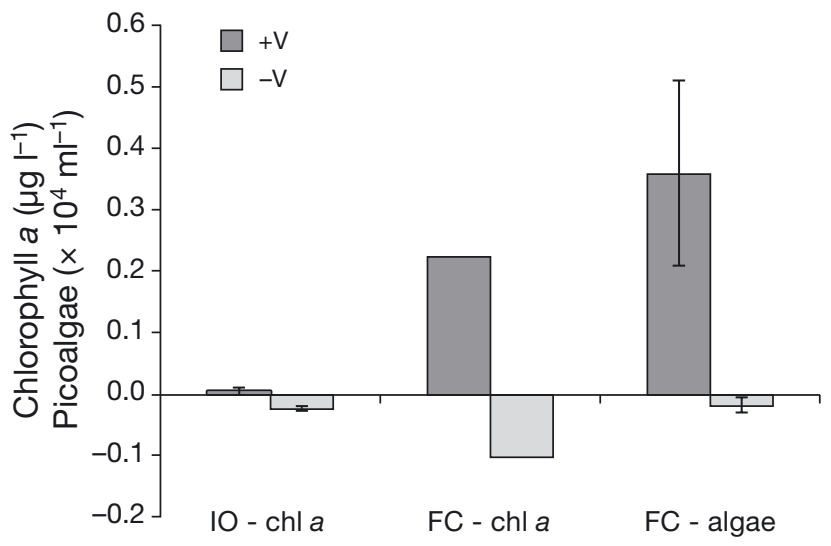

Fig. 2. Increase in $+\mathrm{V}$ and $-\mathrm{V}$ from initial to final time point of chlorophyll a (chl a) concentrations from IO and FC experiments, and abundances of picoalgae from the FC experiment, in which viruses had been reduced $(-\mathrm{V})$ or maintained at near in situ abundance $(+\mathrm{V})$. Error bars represent the SD of abundance estimates from triplicate incubations. Chl a for FC has no replicates

These results imply that viruses are important but neglected agents of ammonium regeneration in a range of marine environments.

Diluting the viral size fraction with ultrafiltered seawater resulted in significantly less net ammonium production in both experiments. Ammonium production concurrent with a decrease in the abundance of bacteria supports the hypothesis that viral lysis of bacteria, followed by subsequent processing by uninfected cells, was the source of the observed ammonium increase. Viral lysates are rich in free and combined amino acids (Middelboe \& Jørgensen 2006), and bacterial mineralization of these compounds is associated with the production of ammonium (e.g. Hollibaugh 1978, Haaber \& Middelboe 2009, Boras et al. 2010). In turn, viral-induced ammonium regeneration resulted in increased growth of phytoplankton, thus implying that viral infection is an important mechanism in $\mathrm{N}$ recycling in the sea. The effect was observed under oligotrophic oceanic conditions as well as under coastal conditions, and is consistent with observations that the growth of Synechococcus in the ocean is associated with the lysis of heterotrophic bacteria (Weinbauer et al. 2011).

\section{Increases in chl $a$ and picoalgae}

Increases in chl $a$ in the presence of the ambient viral community relative to treatments in which viral abundances were reduced is consistent with ammonium increases in the $+\mathrm{V}$ treatments supporting 


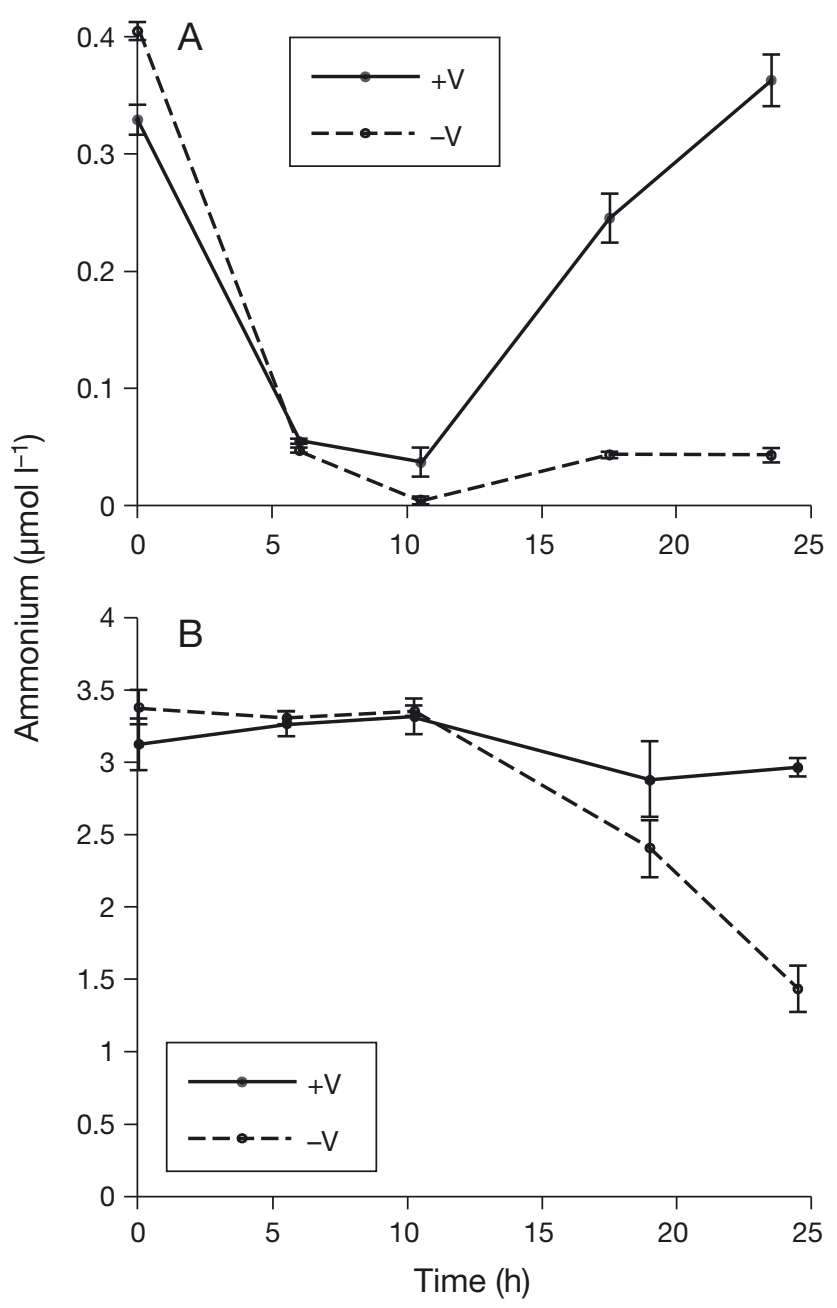

Fig. 3. Time series of ammonium concentrations in seawater samples from (A) Indian Ocean and (B) False Creek experiments in which viruses had been reduced $(-\mathrm{V})$ or maintained at near in situ abundance $(+\mathrm{V})$. Error bars represent the SD of abundance estimates from triplicate incubations

increased phytoplankton growth (Fig. 2). Interestingly, the dilution of the viral size fraction in $-\mathrm{V}$ resulted in less phytoplankton biomass and chl a concentrations in both experiments, indicating that phytoplankton production depended on viral lysis of bacteria.

\section{Impact of grazers}

Contribution to the DOM pool by grazers cannot be excluded from either experiment, although in the FC experiment grazers were undetectable $\left(<10^{4}\right.$ cells $\left.\mathrm{ml}^{-1}\right)$. Infection of grazers by viruses might have occurred (e.g. Saura et al. 2011), but would not change the results, because infection would sim- ply provide another source of virus-induced DOM to the treatment, intensifying the results. Grazing of viruses may also have occurred; however, removal rates are generally minimal relative to the large standing stock of viruses (Gonzalez \& Suttle 1993, Bettarel et al. 2005).

\section{Ecological implications}

Significant rates of viral mediated ammonium regeneration in both oligotrophic oceanic and productive coastal environments emphasise the importance of viruses in regenerating $\mathrm{N}$ and supporting phytoplankton production. Unlike carbon, for which viral lysis of bacteria has been considered a futile loop (Azam \& Worden 2004), N remineralisation by viruses appears to be an important process in both low- and high-productivity regions of the oceans. Our results show that the removal of viruses reduces ammonium production and decreases phytoplankton growth, supporting evidence from other studies in which the removal of viruses decreases growth rates of Synechococcus (Weinbauer et al. 2011).

The dependence of phytoplankton growth on $\mathrm{N}$ regeneration mediated by viral lysis is a feedback mechanism that has not previously been documented, and which is likely significant on a global scale. Instead of acting as a carbon sink, viral activity stimulates $\mathrm{N}$ recycling that, in turn, fuels primary production and system productivity. Assuming global bacterial production of 26 to $70 \mathrm{Gt} \mathrm{C} \mathrm{yr}^{-1}$ (Ducklow \& Carlson 1992), a loss from viral lysis of 20 to $40 \%$ of the production (Suttle 1994, 2005), and a bacterial C:N of 5, the global annual production from viral lysis would be $\sim 1$ to 6 Gt N. Compared with an estimated annual global marine primary production of 49.3 Gt C (Ducklow \& Carlson 1992), this corresponds to a demand by phytoplankton of approximately 7.4 Gt $\mathrm{N}$ (according to the Redfield ratio). Hence, viral lysis is potentially responsible for supplying a large portion of the global $\mathrm{N}$ requirements of phytoplankton.

Acknowledgements. This work was supported by grants from the Danish Natural Sciences Research Council, the Carlsberg Foundation and the Danish Expedition Foundation to M.M., and by awards to C.A.S. and E.J.S. from the Natural Sciences and Engineering Research Council of Canada. Part of the present work was carried out during the Galathea3 expedition under the auspices of the Danish Expedition Foundation. This is Galathea3 contribution no. P 88. 


\section{LITERATURE CITED}

Azam F, Worden AZ (2004) Microbes, molecules, and marine ecosystems. Science 303:1622-1624

> Bettarel Y, Sime-Ngando T, Bouvy M, Arfi R, Amblard C (2005) Low consumption of virus-sized particles by heterotrophic nanoflagellates in two lakes of the French Massif Central. Aquat Microb Ecol 39:205-209

Boras JA, Sala MM, Arrieta JM, Sà EL and others (2010) Effect of ice melting of bacterial carbon fluxes channelled by viruses and protists in the Arctic Ocean. Polar Biol 33:1695-1707

Bratbak G, Thingstad F, Heldal M (1994) Viruses and the microbial loop. Microb Ecol 28:209-221

$>$ Brussaard CPD (2004) Optimization of procedures for counting viruses by flow cytometry. Appl Environ Microbiol 70:1506-1513

Ducklow HW, Carlson CA (1992) Oceanic bacterial production. In: Marshall KC (ed) Advances in microbial ecology. Plenum Press, New York, NY, p 113-181

Fuhrman JA (1992) Bacterioplankton roles in cycling of organic matter: the microbial food web. In: Falkowski PG, Woodhead AD (eds) Primary productivity and biogeochemical cycles in the sea. Plenum Press, New York, NY, p 361-382

Fuhrman JA (1999) Marine viruses and their biogeochemical and ecological effects. Nature 399:541-548

- Fuhrman JA, Azam F (1980) Bacterioplankton secondary production estimates for coastal waters of British Columbia, Antarctica, and California. Appl Environ Microbiol 39:1085-1095

Gobler CJ, Hutchins DA, Fisher NS, Cosper EM, SanudoWilhelmy S (1997) Release and bioavailability of C, N, P, $\mathrm{Se}$, and Fe following viral lysis of a marine chrysophyte. Limnol Oceanogr 42:1492-1504

Goldman JC, Caron DA, Dennett MR (1987) Regulation of gross growth efficiency and ammonium regeneration in bacteria by substrate C:N ratio. Limnol Oceanogr 32: 1239-1252

González JM, Suttle CA (1993) Grazing by marine nanoflagellates on viruses and virus-sized particles: ingestion and digestion. Mar Ecol Prog Ser 94:1-10

Haaber J, Middelboe M (2009) Viral lysis of Phaeocystis pouchetii: implications for algal population dynamics and heterotrophic $\mathrm{C}, \mathrm{N}$ and $\mathrm{P}$ cycling. ISME J 3:430-441

Hollibaugh JT (1978) Nitrogen regeneration during the degradation of several amino acids by plankton communities collected near Halifax, Nova Scotia, Canada. Mar Biol 45:191-201

Editorial responsibility: Gunnar Bratbak, Bergen, Norway
Holmes RM, Aminot A, Kerouel R, Hooker BA, Peterson BJ (1999) A simple and precise method for measuring ammonium in marine and freshwater ecosystems. Can J Fish Aquat Sci 56:1801-1808

Middelboe M, Jørgensen NOG (2006) Viral lysis of bacteria: an important source of dissolved amino acids and cell wall compounds. J Mar Biol Assoc UK 86:605-612

- Middelboe M, Lyck PG (2002) Regeneration of dissolved organic matter by viral lysis in marine microbial communities. Aquat Microb Ecol 27:187-194

Middelboe M, Jørgensen NOG, Kroer N (1996) Effects of viruses on nutrient turnover and growth efficiency of non-infected marine bacterioplankton. Appl Environ Microbiol 62:1991-1997

Middelboe M, Riemann L, Steward GF, Hansen V, Nybroe O (2003) Virus-induced transfer of organic carbon between marine bacteria in a model community. Aquat Microb Ecol 33:1-10

Olsen R, Zettler E, DuRand M (1993) Phytoplankton analysis using flow cytometry. In: Kemp P, Sherr B, Sherr E, Cole $\mathrm{J}$ (eds) Handbook of methods in aquatic microbial ecology. Lewis, Boca Raton, FL, p 175-197

Parsons T, Maita Y, Lalli C (1984) A manual of chemical and biological methods for seawater analysis. Pergamon Press, Oxford

Saura A, Massana R, Boras JA, Forn I, Vila-Reixach G, Vaqué D (2011) Effect of viruses on marine stramenopile (MAST) communities in an oligotrophic coastal marine system. J Plankton Res 33:1709-1718

Short SM, Suttle CA (2003) Temporal dynamics of natural communities of marine algal viruses and eukaryotes. Aquat Microb Ecol 32:107-119

> Suttle CA (1994) The significance of viruses to mortality in aquatic microbial communities. Microb Ecol 28: $237-243$

Suttle CA (2005) Viruses in the sea. Nature 437:356-361

Suttle CA (2007) Marine viruses-major players in the global ecosystem. Nat Rev Microbiol 5:801-812

Weinbauer MG, Bonilla-Findji O, Chan AM, Dolan JR and others (2011) Synechococcus growth in the ocean may depend on the lysis of heterotrophic bacteria. J Plankton Res 33:1465-1476

Wilhelm SW, Suttle CA (1999) Viruses and nutrient cycles in the sea: viruses play critical roles in the structure and function of aquatic food webs. Bioscience 49:781-788

Wilhelm SW, Bridgen SM, Suttle CA (2002) A dilution technique for the direct measurement of viral production: a comparison in stratified and tidally mixed coastal waters. Microb Ecol 43:168-173

Submitted: September 19, 2011; Accepted: January 10, 2012 Proofs received from author(s): March 6, 2012 